\title{
2012 impact factor of the Pol Arch Med Wewn: new challenges and hopes
}

\author{
Anetta Undas \\ Editor-in-Chief, Polish Archives of Internal Medicine
}

Correspondence to:

Prof. Anetta Undas, MD, PhD,

Instytut Kardiologii, Uniwersytet

Jagielloński, Collegium Medicum

ul. Prądnicka 80, 31-202 Kraków,

Poland, phone: + 48-12-614-30-04

fax: +48-12-423-39-00, e-mail:

mmundas@cyfkr.edu.pl.

Received: June 28, 2013

Accepted: June 28, 2013

Conflict of interest: none declared.

Pol Arch Med Wewn. 2013;

123 (7-8): 350-352

Copyright by Medycyna Praktyczna Kraków 2013
Dear Readers, Dear Colleagues!

Good news for our journal, the Polish Archives of Internal Medicine (Pol Arch Med Wewn) - a monthly, peer-reviewed journal devoted to the publication of research on internal medicine and published on behalf of the Polish Society of Internal Medicine and in partnership with the publisher Medycyna Praktyczna.

I am delighted to provide you with the latest impact factor. The 2012 Journal Citation Report has been released by Thomson Reuters. Our impact factor has increased from 1.367 in 2011 to 1.833 in 2012, which is our great success. I would like to thank you all - our authors, reviewers, and editorial and scientific board members - for your invaluable contribution to the journal's success.

The impact factor in a given year is the average number of citations a paper published in that journal received during the two previous years. It is a widely acknowledged measure of journal quality and it is currently the best available bibliometric index. Therefore, I am proud of our achievement in 2012, in particular when compared with other Polish medical journals (TABLE 1). However, the value and use of this evaluation system keep raising controversies as evidenced by some titles of the recently published articles, for example, "Overthrowing the tyranny of the journal impact factor" by Magnus B. ${ }^{1}$ Bruce Alberts, the Editor-in-Chief of Science, wrote on May 17, 2013: "The misuse of the journal impact factor is highly destructive, inviting a gaming of the metric that can bias journals against publishing important papers in fields that are much less cited than others."2 As stated in his editorial, scientists should not be "ranked by weighting each of their publications according to the impact factor of the journal in which it appeared."

In most Polish medical universities, this is a rule which distorts (accompanied by an absurd mere number of all researcher's papers) the actual researcher's value, in particular, in clinical medicine

TABLE 1 Polish journals with the highest impact factor 2012

\begin{tabular}{lll} 
Title & ISSN & Impact factor \\
Ann Agr Env Med & $1232-1966$ & 3.060 \\
\hline Acta Astronom & $0001-5237$ & 2.682 \\
\hline J Physiol Pharmacol & $0867-5910$ & 2.476 \\
\hline Arch Immunol Ther Ex & $0004-069 X$ & 2.378 \\
\hline Acta Neurobiol Exp & $0065-1400$ & 1.977 \\
\hline Cell Mol Biol Lett & $1425-8153$ & 1.953 \\
\hline J Appl Genet & $1234-1983$ & 1.847 \\
\hline Pol Arch Med Wewn & $\mathbf{0 0 3 2 - 3 7 7 2}$ & 1.833 \\
\hline Hered Cancer Clin Pr & $1731-2302$ & 1.714 \\
\hline Acta Ornithol & $0001-6454$ & 1.681 \\
\hline Geochronometria & $1733-8387$ & 1.653 \\
\hline Acta Paleontol Pol & $0567-7920$ & 1.577 \\
\hline Folia Neuropathol & $1641-4640$ & 1.547 \\
\hline Psychiatr Pol & $0033-2674$ & 1.480 \\
\hline Cent Eur J Energ Mat & $1733-7178$ & 1.327 \\
\hline
\end{tabular}


TABLE 2 Papers published in 2010-2011 which were most cited in 2012

\begin{tabular}{lll} 
Article & Year of publication & Number of citations \\
Szułdrzyński et al. ${ }^{4}$ & 2010 & 10 \\
\hline Brodersen et al. $^{5}$ & 2010 & 7 \\
\hline Banach and Aronow $^{6}$ & 2011 & 6 \\
\hline Holecki and Wiecek $^{7}$ & 2010 & 6 \\
\hline Bijlsma $^{8}$ & 2010 & 6 \\
\hline Staszel et al. $^{9}$ & 2011 & 5 \\
\hline Rewiuk et al. $^{10}$ & 2011 & 5 \\
\hline Smykat-Jankowiak et al. $^{11}$ & 2011 & 5 \\
\hline Douketis $^{12}$ & 2011 & 5 \\
\hline
\end{tabular}

in the era of large multicenter trials providing not only the high-profile journal publications, but also a large number of citations. It should also be kept in mind that there is a rather weak positive correlation between the citation frequency of the articles and the impact factor of the journals in which they have been published. In my opinion, from a Polish perspective, not only "scientists maintain the polite fiction that all of them are equal and do equally good science", ${ }^{3}$ but also journals maintain a similar illusion. In Poland, an equal amount of money is offered by a government to support biomedical journals of long-term tradition with the impact factor of 0 and those with the impact factor of 2 or more. No reward for a higher impact factor results, in most cases, in a negligible improvement (if any) in journal quality. Without promoting the best national journals, good science, decent universities, and, finally, practical use of scientific achievements will be another illusion of grave consequences for the whole still aspiring nation.
Even if the impact factor has hard time, its value is still the best way to compare the journals and helps support the good ones by public funds. Coping with the continued financial problems, I still appreciate the financial support of the Pol Arch Med Wewn by the Polish Ministry of Science and Higher Education and do count on fundamental changes in the crippled system of supporting scientific journals by public funds in Poland.

The most cited papers published in 2010 or 2011 are listed in TABLE 2. Of note, the most cited paper among those published in 2010 and 2011 was an original paper and not a review, which usually contributes most to the journal's impact factor.

During our first year with the impact factor, a boost in submissions has been observed. Our journal attracts an increasing number of higher-quality papers and the scope of the submitted material is even broader. The rejection rate is going up to more than $70 \%$ and we can be more selective. The time to first decision is still about
FIGURE Contents of the first issue of the Polish Archives of Internal Medicine (1923); courtesy of the Medical Library of the Jagiellonian University Medical College

\section{TOM PIERWSZY. ZESZYT PIERWSZY. \\ SOMMAIRE.}

SPIS RZECZY.

1. W sprawie rozpoznawania kity (syphilis) pluc. Prof. Dr. A. Gluziński . . . . . .

2. Badania porównawcze nad różnymi sposobami wykazywania niewydolności wątroby. Dr. W. Filiński i Dr. W. Proszowski. .

3. O zachowaniu sie tluszczów obojętnych we krwi u ludzi zdrowych i chorych. Dr. Zdzisław Gorecki

4. Badania nad cholesterynemia Prof. Dr. Witold Orłowski.

5. Spostrzeżenia nad opadaniem czerwonych ciałek krwi. Dr. fil. i med. Eleonora Reicher .100

6 Badania nad znaczeniem odczynu Pirquet'a. L. Sobieszczański i Zdzisław Michalski . 110

7 Doświadczenia nad zachowaniem sie cukru we krwi i w moczu pod wplywem pilokarpiny u ludzi zdrowych i u dotkniętych moczówką cukrowa Dr. Jakób Węgierko
1. Sur le diagnostic des affections syphilitiques des poumons; par Prof. Dr. A. Gluziński . . . 135

2. Recherches sur les différentes méthodes de l'examen de l'insuffisance hépatique; par W. Filiński et W. Proszowski . . 137

3. Recherches sur la quantité des graisses neutres dans le sang; par Z. Gorecki, dr. en med. 132

4. Recherches sur la cholestérinémie; par Prof. Dr. W. Orłowski . . . 139

5. Observations sur la sèdimentation des globules rouges du sang; par Eleonora Reicher, dr. en phil et en med. . . . 141

6. Recherches sur la cuti-réaction. de Pirquet; par L. Sobieszczański et Z. Michalski ... 143

7. Expériences sur les modifications de la quantité du sucre dans le sang et les urines sous l'influence de la pilocarpine: par Dr. J. Wegierko ?... 14 ! 
22 days. The journal enjoys a good readership and I hope it continues to appeal to its original subscribers.

A few supporters and friends of our journal including the President of the Society of Internal Medicine do feel that the journal's visibility is hampered by its Polish name, Polskie Archiwum Medycyny Wewnętrznej (Pol Arch Med Wewn, which stands for Polish Archives of Internal Medicine). It is the original title and has remained unchanged since 1923. The first issue of the journal, containing 14 articles on 144 pages, has been scanned with the permission of the Jagiellonian Library in Krakow and is now available on our website (www.pamw.pl) for all those who are interested in clinical problems that attracted the attention of Polish scientists and internists 90 years ago (FIGURE).

While the archival first issue is in Polish, the current issue, celebrating the 90th anniversary of the Pol Arch Med Wewn, contains 2 articles on most distinguished Polish internists and the history of the journal for English-speaking readers. ${ }^{13,14}$ So, is it now time to make the title of our journal "more international", namely, the Polish Archives of Internal Medicine? Not in 2013. I agree that the change of the title, with its predicted ef fect on the quality and impact of submissions, could help promote Polish clinical science. However, since "a rose by any other name would smell as sweet” (William Shakespeare, Romeo and Juliet), my personal opinion is that our national journal could be increasingly acknowledged even with its original title in one of the most difficult Indo-European languages. Am I right? Time and members of our Society will tell.

I look forward to the ongoing support of Polish researchers and clinicians in the years to come, so that together we may continue to enhance the quality of science published in the Pol Arch Med Wewn with a further increase in the impact factor of 2 or more in 2013 and beyond.

\section{REFERENCES}

1 Magnus D. Overthrowing the tyranny of the journal impact factor. Am J Bioeth. 2013; 13: 1-2.

2 Alberts B. Impact Factor distortions. Science. 2013; 340: 787.

3 Łomnicki A. Impact factors reward and promote excellence. Nature. 2003; 424:487.

4 Szułdrzyński K, Zalewski J, Machnik A, Zmudka K. Elevated levels of 8-iso-prostaglandin F2alpha in acute coronary syndromes are associated with systemic and local platelet activation. Pol Arch Med Wewn. 2010; 120 : 19-24.

5 Brodersen J, Jørgensen KJ, Gøtzsche PC. The benefits and harms of screening for cancer with a focus on breast screening. Pol Arch Med Wewn 2010; 120: 89-94.

6 Banach M, Aronow WS. Should we have any doubts about hypertension therapy in elderly patients?: ACCF/AHA 2011 expert consensus document on hypertension in the elderly. Pol Arch Med Wewn. 2011; 121: 253-258.

7 Holecki M, Wiecek A. Relationship between body fat mass and bone metabolism. Pol Arch Med Wewn. 2010; 120: 361-367.

8 Bijlsma JW. Optimal treatment of rheumatoid arthritis: EULAR recommendations for clinical practice. Pol Arch Med Wewn. 2010; 120: 347-353.

9 Staszel T, Zapała B, Polus A, et al. Role of microRNAs in endothelial cell pathophysiology. Pol Arch Med Wewn. 2011; 121: 361-366.
Rewiuk K, Wizner B, Fedyk-tukasik M, et al. Epidemiology and management of coexisting heart failure and atrial fibrillation in an outpatient setting Pol Arch Med Wewn. 2011; 121: 392-399.

11 Smykat-Jankowiak K, Niemir ZI, Polcyn-Adamczak M. Do circulating antibodies against C1q reflect the activity of lupus nephritis? Pol Arch Med Wewn 2011; 121: 287-295.

12 Douketis J. Dabigatran as anticoagulant therapy for atrial fibrillation Which patients should receive it, which patients may not need it, and other practical aspects of patient management. Pol Arch Med Wewn. 2011; 121 73-80.

13 Kucharz EJ. The man behind the journal: Editors-in-Chief of the Polish Archives of Internal Medicine (1923-2013). Pol Arch Med Wewn. 2013; 123: 339-346.

14 Supady J. Distinguished Polish internists: Witold E. Ortowski and Mściwój M. Semerau-Siemianowski. Pol Arch Med Wewn. 2013; 123: 347-349. 